MirosŁaWA ŚCIUPIDER-MŁODKOWSKA

ORCID 0000-0002-8700-2249

Uniwersytet im. Adama Mickiewicza

$w$ Poznaniu

\title{
RODZINA I MIŁOŚĆ W EPOCE JA. WYZWANIA DLA PEDAGOGIKI
}

\begin{abstract}
AвSTRACt. Ściupider-Młodkowska Mirosława, Rodzina i miłość w epoce Ja. Wyzwania dla pedagogiki [Family and Love in the Time of Me. Challenges for Pedagogy]. Studia Edukacyjne nr 54, 2019, Poznań 2019, pp. 147-159. Adam Mickiewicz University Press. ISSN 1233-6688. DOI: 10.14746/se.2019.54.9
\end{abstract}

The theoretical part of this article draws on terminology defined by theorists such as J. C. Kauffman, N. Luhmannn, Ch. Lasch, E. Beck-Gernsheim, U. Beck, A. Giddens, L. Jamienson, E. Illouz, and Z. Bauman. The research on partnership relations in the narcissistic culture are published in the book by the article author: Ściupider-Młodkowska M., Love in the time of Me. A socio-pedagogical study, Poznań 2018. The fight for an approval and innovatory ideas for a happy partnership life (which has been observed in my research on biographies of relationships) does not entirely come from "free" choices. Therefore, we may conclude that to some extent the culture of narcissism has an impact on a quality of relationships and relations between people in general. In the wider context, the article tries to provide an answer to the question of transgression of common responsibility for a success or a failure in relations between people. Interpersonal contacts are increasingly controlled or created by the market as well as the world of technicization. As a result, their character is changed into shortterm relations where only an Ego of individuals is promoted and general narcissism culture is spread. Pedagogues are concerned about building identity of young people mostly in social media according to the phrase Selfie ergo sum. Pedagogy cannot ignore the influence of media on the social development of teenagers (which includes their sexual development, too). To prevent the acquisition of negative patterns, an educational program needs to be proposed which will teach a critical approach to social media and help build sustained interpersonal relations.

Key words: love in the time of Me, relations in social pedagogy, the culture of narcissism, the value of recognition and voyeurism in the media

\section{Wstęp}

Rodzina stanowi podstawę do rozwijania i budowania społecznych, instytucjonalnych, kulturowych i niepowtarzalnych relacji potrzebnych wspólnocie. Rodzina i miłość silnie ze sobą kooperują. To rodzina daje podstawę do 
przeżywania miłości macierzyńskiej, ojcowskiej, siostrzanej, braterskiej, ale także miłości toksycznej, której konsekwencje ponosi nie tylko osoba, która jej doświadczyła, ale całe następne pokolenia. Miłość raniąca, krzywdząca bardzo często nieświadomie niesie ze sobą piętno osamotnienia, wykluczenia i trudności w nawiązywaniu bliskich relacji związkowych. Dlatego, cały nurt psychologii humanistycznej, psychologii osobowości oraz nurt działań systemowych dostrzegają ogromny wpływ doświadczeń biograficznych związanych z tak zwaną miłością trudną, czy toksyczną, będących bezpośrednim źródłem problemów w życiu dorosłym, takich jak na przykład: depresja, alkoholizm, zakupoholizm, bulimia, anoreksja i wiele innych chorób z kręgu wymagających wsparcia i specjalistycznej pomocy. Wpływ i udział rozwijających się badań psychologicznych, będących pomocnymi w budowaniu wspólnoty i relacji jest ogromny, niezwykle potrzebny i wartościowy.

Celem niniejszego artykułu jest zaakcentowanie, że współczesne zmieniające się uwarunkowania społeczno-kulturowe są paralelne $\mathrm{w}$ stosunku do uwarunkowań indywidualnych i rodzinnych, gdyż wpływają z równą siłą na rozumienie i definiowanie uczuć, emocjonalności, miłości, będących w centrum jakichkolwiek relacji. Miłość ma ogromną moc sprawczą. Według Niclasa Luhmana ${ }^{1}$ obok pieniądza i władzy stanowi podstawę oddziaływania na całe struktury społeczne, toteż tym bardziej warta jest analiz naukowych. W niniejszym artykule ukazano i zdefiniowano niektóre ogólnodostępne kody emocjonalności oraz miłości, które usankcjonowały konkretne badania, między innymi autorski projekt na temat biografii związkowych wśród młodzieży studiującej w wybranych uczelniach polskich i czeskich w latach 2013-2016².

Podjęty cel zanalizowania kształtu współczesnych relacji międzyludzkich jest uzasadniony z kilku względów.

Po pierwsze, z jednej strony obserwujemy hybrydowość, różnorodność relacji rodzinnych zmienionych $\mathrm{z}$ modelu patriarchalnego na rzecz relacji dbających o jakość, ale też zaklasyfikowanych do relacji kruchych, efemerycznych, krótkotrwałych, często elektronicznych i wyimaginowanych. Biorąc pod uwagę, jak długą drogę przebyła tak zwana rodzina tradycyjna i jak znacząco zmienił się jej model z czasów preindustrialnych, nie można zostać obojętnym wobec ich przemian i zbadania zarówno w kontekście szans, jak też zagrożeń.

Po drugie, pedagogika społeczna, będąca in statu nascendi w wypracowaniu odpowiednich narzędzi i metod badających relacje on-line, w tym także

\footnotetext{
${ }^{1}$ N. Luhman, Semantyka mitości. O kodowaniu intymności, Warszawa 2003.

${ }^{2}$ Badania do dysertacji doktorskiej, obronionej pod kierownictwem J. Modrzewskiego na Wydziale Studiów Edukacyjnych, realizowane dzięki stypendium Fundacji Uniwersytetu im. Adama Mickiewicza w Poznaniu, w całości opublikowane w książce: M. Ściupider-Młodkowska, Mitość w epoce Ja. Studium socjopedagogiczne, Poznań 2018.
} 
$\mathrm{w}$ budowaniu odpowiedniej sieci wsparcia wobec obecnych $\mathrm{w}$ przestrzeni wirtualnej przestępstw: cyberstalkingu, sekstingu, sponsoringu, rozpoznaje tło społeczno-kulturowe i rodzinne odpowiedzialne za problemy społeczne. Zatem, troska o jakość relacji rodzinnych i miłosnych, aby z jednej strony stanowiły bastion, nierozerwalną wspólnotę, $\mathrm{z}$ drugiej strony nie były powodem do dyskryminacji, stanowi siłę napędową do działań społecznych, politycznych, wspierających różne formy rodziny. Takie próby w naukach społecznych są już podejmowane we wspaniałych projektach na temat równości osób nieheteroseksualnych $w$ Polsce $w$ badaniach etnograficznych realizowanych między innymi przez Agatę Stasińską ${ }^{3}$.

\section{Współczesna wartość bycia razem, czyli tak zwana „bliskość w tle"}

Miłość obecna w kulturze narcyzmu, którą Christopher Lasch ${ }^{4}$ zauważył dwadzieścia siedem lat temu, kiedy w społeczeństwie amerykańskim przemiany ekonomiczne i wzrost konsumpcji życia ",zaowocowały” ogólnodostępnym trendem samodoskonalenia jednostki, ma swoje źródło w dążeniu do wymiernej korzyści i rywalizacji (walki o uznanie) niemal w każdej sferze życia. Miłość od tego momentu nie jest już jedynie indywidualnym projektem, lecz została uwikłana w media, instytucje, rynek, reklamę, w dużej mierze kształtowana przez społeczne relacje płci i ekonomię. Taka relacja doczekała się często metaforycznych określeń w naukach społecznych, jak: bycie razem osobno (Zygmunt Bauman), miłość współbieżna albo czysta (Anthony Giddens), relacja zwana "bliskością w tle" lub „intimate ambient” (Shery Turkle). Wszystkie sformułowania i hasła wokół miłości, które jedynie zasygnalizowano łączy znamienne poczucie niepewności i braku bezpieczeństwa, bowiem silny akcent kładą na emocje związane nie z bliskością, ale samotnością/osamotnieniem, nie z jednością, ale wykluczeniem, nie z poczuciem dumy, ale wstydu, nie z odpowiedzialnością za podjęte decyzje, ale krótkoterminowością i łatwością rozstania. Duch samodoskonalenia obecny w każdej sferze życia: zdrowotnej, intelektualnej, rodzinnej, zawodowej oraz kult kultury Ja poddający treningowi osobowość dążącą do wolnych decyzji, w dużej mierze manipulował związkami i relacjami międzyludzkimi oraz skłaniał do „zabójczej gry onieśmielania przyjaciół i uwodzenia ludzi”", co z kolei rodziło cierpienie i osamotnienie. 2018.

${ }^{3}$ A. Stasińska, Socjologia pary. Praktyki intymne w zwiazkach nieheteroseksualnych, Kraków

${ }^{4}$ Ch. Lasch, Kultura narcyzmu, Warszawa 2015, s. 93. 
Nie jest wielkim odkryciem, że zaangażowanie w relację miłosną od zawsze wiązało się z pewnym cierpieniem, tak pięknie opisanym chociażby w literackiej formie miłości romantycznej czy sentymentalnej, jak na przykład Romea i Julii czy Tristana i Izoldy. Współczesne relacje ranią nie tylko z przyczyn indywidualnego zaangażowania, czy sprzeczności interesów i protekcji rodów pochodzenia kochanków, ale także, a może przede wszystkim, z przyczyn kulturowego narcyzmu, takich jak niepewność, chaos tożsamości, paniczne poszukiwanie uznania nie tylko w przestrzeni wirtualnej. Nauka, technologia i wpływy polityczne w silnym stopniu zracjonalizowały miłość, jak udowadnia izraelska badaczka E. Illouz ${ }^{5}$. Zgodnie $\mathrm{z}$ analizami autorki, rozbuchane ogólnodostępne technologie, pozwalające na bycie ogólnodostępnym poszukującym idealnego partnera, zafałszowały intencje emocji; partnerzy, jako kreatorzy czy budowniczy - homo construens, pogubili się, co stanowi cel relacji, czym jest zaangażowanie, poznanie drugiej osoby. Tym sposobem miłość uległa swego rodzaju odczarowaniu, skomercjalizowaniu, wymianie interesów.

Trafnie zjawisko wykreowanej internetowej relacji bez zaangażowania opisał Michał Wanke:

Być związanym z kimś z "bliskością w tle” to być obecnym w jego życiu ze swoją upublicznioną prywatnością. Być z kimś „razem osobno” (...) to odgrywać swoją tożsamość on-line potencjalnie przed całym światem tych, którzy mają urządzenie z dostępem do sieci. Wreszcie być z kimś intimate ambient to podglądać strumień jego tożsamości bez zaangażowania, jakiego wymagałby tak nasycony informacjami związek poza światem Internetu ${ }^{6}$.

Bycie w ciągłym kontakcie z kimś daje iluzję bycia ważnym i potrzebnym, uwalnia od zobowiązań względem bliskich relacji rodzinnych, z drugiej strony łudzi obietnicą, że tego typu wirtualne zaangażowanie zapełni potrzebę niepowtarzalności, przezwycięży zwyczajność i niewidzialność w wielkim tłumie znajomych, czy tak zwanych "przyjaciół”, komentujących na forum zawiązywanie/zrywanie relacji.

Kultura narcyzmu, przejawiająca się w wyszukanych środkach komunikacji wirtualnej skierowanej na "Ja" jednostki, silnie wkracza w uczuciowość i tym samym przyczynia się do zmian w podejściu do ogólnych relacji międzyludzkich, niejednokrotnie je uprzedmiotawiając. Obecny na portalu randkowym "tinder" sposób weryfikacji potencjalnych partnerów na podstawie wieku, orientacji seksualnej oraz odległości geograficznej, w jakiej potencjalni randkowicze się od nas znajdują, sprowokował do upowszechnienia kodu

\footnotetext{
${ }^{5}$ E. Ilouz, Dlaczego miłość rani. Studium socjologiczne, Warszawa 2016.

${ }^{6} \mathrm{M}$. Wanke, E-mocje, przypadki rozszerzonej rzeczywistości afektywne, [w:] Studia z socjologii emocji. Podręcznik akademicki, red. A. Czerner, E. Nieroba, Opole 2011.
} 
komunikacji młodzieżowej: Lewa/Prawa. Oznacza on tyle, co akceptuję Jej/ Jego wygląd, czyli "prawa” lub odrzucam - "lewa”. Fakt ten dowodzi, że użytkownicy spotkań on-line nie zaprzestają stosowania pewnych antropotechnik w życiu codziennym: do języka młodzieżowego obfitującego w skróty myślowe można dodać ikonowe znaki komunikacyjne stosowane w relacjach rówieśniczych dla okazania uczucia, zainteresowania. Korespondując, a coraz częściej rozmawiając, operują pewnymi skrótami i kodami myślowymi, używając tak zwanych ",witaczy", ,emotikonów”, , "laików” oraz innych symboli w nazewnictwie, które zaproponował im system i dany portal społecznościowy. Bylejakość w nazywaniu swoich emocji, uczuć przekłada się bardzo wyraźnie na obserwowane uprzedmiotowienie w kontaktach. Ponadto, możliwość wielorakiego wyboru partnera oferowana na portalach randkowych i społecznościowych przyzwyczaja jednostki żyjące jednocześnie w krajobrazie medialnych wrażeń, jak i szarym życiu codziennym do ciągłego głodu poszukiwania „lepszej opcji” i ciągłej potrzeby uznania w świecie realnym. Medialnym szokującym przykładem poszukiwania tego typu wrażeń jest film dokumentalny: „Nie jesteśmy puszczalskie"7 z 2009 roku, w którym nieletnie licealistki opowiadają o swojej rozwiązłości seksualnej, nie zaliczając jej do prostytucji, ale fantastycznej przygody, dzięki której urozmaicają (czytaj "dopalają") swoje przeciętne życie. Maria Czerpaniak-Walczak udowadnia, że mącenie $\mathrm{w}$ wartościach oraz wszelkiego rodzaju zaburzenia i braki osobowościowe występują z taką samą siłą i częstotliwością zarówno w środowiskach cierpiących na niedobory emocjonalne, socjalne, co w socjalizacji pełnej nadmiaru i obfitości.

Doświadczenia życia codziennego w warunkach obfitości, przeładowania, stłoczenia, przeciążenia, bogactwa, naddatków i innych przejawów nadmiaru także mogą przeciążać i wyczerpywać zasoby fizyczne, emocjonalne i intelektualne oraz prowadzić do zaburzeń.

(...) Wraz z użyciem coraz bardziej wyrafinowanych technicznie środków poszerza się zakres treści i form upowszechniania wzorów i norm relacji społecznych oraz pracy nad sobą. Zwiększa się przy tym zamęt w obszarze wzorców osobowego i społecznego rozwoju ${ }^{8}$.

Zamęt ten wpływa na deprecjacje i dewaluacje pojęcia „My" na rzecz nobilitacji "Ja" w biografiach związkowych.

W latach osiemdziesiątych w tygodniku „Polityka” opublikowano artykuł charakteryzujący polski model kobiet z lat 1980-1989, w którym kobiety

7 Polski film dokumentalny: „Nie jesteśmy puszczalskie” w reżyserii Atheny Sawidis z 2009 roku.

${ }^{8}$ M. Czerpaniak-Walczak, Socjalizacja akademicka w czasach nadmiaru. O socjalizacji w (akademickim) krajobrazie medialnym, [w:] Pedagogika w społeczeństwie - społeczeństwo w pedagogice, red. A. Matysiak-Błaszczyk, E. Włodarczyk, Poznań 2016, s. 195-200. 
„marzą o bogatym mężu i domku z ogródkiem, ale zburzą te marzenia, gdy tylko przekonają się jak ograniczający bywa taki model życia" ${ }^{\prime 9}$. W tych latach rośnie popularność tak zwanych ",książek z serduszkiem”, czyli Harlequinów, opisujących piękne młode kobiety, romansujące, dążące do podmiotowego traktowania w związkach, uciekające od monotonii małżeństw i negocjujące swoją pozycję w relacji miłosnej. Obecnie swego rodzaju odskocznię od realnych kontaktów pełnią portale randkowe oraz opiniotwórcze rzesze terapeutów, ekspertów i elit odpowiedzialnych za tak zwany refleksyjny model związków uczuciowych. Trzydzieści, czterdzieści lat temu kobiety uciekające w świat książkowych romansów, pod ich wpływem raczej nie podejmowały odważnych, ryzykownych decyzji o rozstaniu, separacji, czy rozwodzie z ówczesnym partnerem. Czytanie tego typu literatury lekkiej służyło raczej rozrywce. Obecnie świat spotkań z wirtualnym kochankiem z rozrywki przekształcił się w angażujące emocjonalnie i czasowo kontakty.

W kulturze zwierzeń internetowych, jednostki tworzące związki realne naturalnie, spontanicznie i chętnie korzystają także z przestrzeni medialnej, która bardzo często wprowadza dezorganizację, zaburzając dotychczasowe życie emocjonalne i intymne, co skutkuje rozpadem tradycyjnych relacji. Internet oraz świat techniki umożliwia znaczne dostarczanie i pobieranie informacji o sobie i innych, tym samym użytkownicy są skazani na "przymusowy” bądź nieuświadomiony "voyeuryzm"10 i podglądactwo. Portale randkowe i społecznościowe, z których korzystają pary, są swoistymi dowodami i bazami danych o partnerach. $Z$ reguły wystarczy jeden pozytywny bądź negatywny komentarz, a nawet upublicznione słowo, na przykład na portalu społecznościowym Facebook, a staje się to powodem awantury i rozpadu relacji realnej. W polskich sądach coraz częstszym powodem rozwodu są właśnie zdrady internetowe.

Rafał Ilnicki ${ }^{11} \mathrm{w}$ nurcie filozoficznej refleksji nad technicyzacją kultury mówi wprost, że każdy użytkownik przestrzeni on-line ma swój wirtualny habitus cyberkulturowy, czyli „traktuje otaczający go świat na wzór tych sposobów bycia, które podsuwa mu technologia". Idąc tym tropem, Ja jednostki w coraz większym stopniu inwestuje w techniki uzewnętrzniania siebie, chcąc zaistnieć w cyberkulturze. Dewaluacja wspólnoty następuje na skutek ujawniania tylko zewnętrznego Ja, które nadyma się różnymi możliwościami retuszowania swojej tożsamości, chwalenia się głównie osiągnięciami - także

${ }^{9}$ Portrety kobiet $i$ mężczyzn w środkach masowego przekazu oraz podręcznikach szkolnych, red. R. Siemieńska, Warszawa 1997, s. 38.

${ }_{10}$ Pojęcie voyeuryzmu oznacza podglądanie medialnych sytuacji i zdarzeń, które u oglądającego uruchamiają fantazje, impulsy (także seksualne), wprowadzając uczucie dyskomfortu oraz frustracji z powodu niemożności realizacji nierealnych i nieosiągalnych pragnień.

${ }^{11}$ R. Ilnicki, Wirtualny habitus cyberkulturowy, Hybris, 2015, 31, s. 37. 
w relacjach miłosnych. Prawdziwe Ja przestaje istnieć, następuje jego dezintegracja, podobnie jak przestaje istnieć realna wspólnotowość w związku, bo jednostka narcystyczna szybko uzależnia się od pochlebstw w świecie wirtualnym, a co gorsza - chce czerpać z tego jedyną satysfakcję.

Wirtualny świat spotkań stwarza iluzję jednostki wolnej, dążącej do spełnienia w każdej sferze życia. Poprzez silną racjonalizację wszystkich pragnień ludzkich wytworzył się nowy typ związków typu „exodus”, czyli uciekających od prawdziwych relacji. Związki te wytworzyły pewien schemat (habitus) bycia razem, w którym oddalają decyzję o stabilizacji i małżeństwie, a nawet realnym spotkaniu. Uciekają głównie od tradycyjnych wzorców związkowych, które krępują oraz od mody, która się demokratyzuje. Związki typu exodus lokują swoje wybory w paradoksach, preferując na przykład bezdzietność z miłości do dzieci, czy też miłosne relacje internetowe z powodu osamotnienia, bycie singlem $\mathrm{w}$ życiu realnym, ale upublicznioną i podziwianą parą w świecie wirtualnym.

Związki, które doświadczają asocjacyjnej funkcji Internetu, reprezentujące typ tak zwanej „bliskości w tle”, w zamian za trwałe i stabilne relacje bardzo często stanowią ich substytut, oferując folklor wrażeń, dowartościowują jedynie zewnętrzny wizerunek jednostek i par. Pary zawiązywane i utrzymywane wyłącznie przez Internet oraz podtrzymujące typ związku uciekającego od realnych spotkań, zaadaptowały i wdrożyły w życie te antropotechniki, które narzucił im system. Separują i emancypują się od otoczenia materialnego jako czegoś gorszego, mniej stymulującego, aniżeli na przykład wirtualne spotkanie z fantastycznie prezentującym się i pod każdym względem atrakcyjnym partnerem. Należy podkreślić, że spotkania on-line są bardzo silnie angażujące emocjonalnie i czasowo; nieustanne fantazjowanie o tym, że można stworzyć związek bez skazy, to żniwo zaszczepienia narcystycznej wizji, że relacja nie może być zwyczajna, bo poświęciliśmy zbyt wiele czasu i energii właśnie na to, aby zaimponować i upublicznić jej niezwykłość.

System wirtualnych spotkań wdraża w odpowiedni schemat wyglądu, prezentacja wizerunku jednostki ulega retuszowi. Pod pozorem jednostek atrakcyjnych, emancypacyjnych, odważnych, jednocześnie kryje się mocno zhomogenizowany świat myśli, wartości, a nawet wyglądu. Okazuje się, że w obietnicy podkreślania dystynktywnych różnic świat on-line czyni jednostki i pary nieodróżnialnymi z danego kręgu, grupy, portalu. W tym homogenicznym świecie nadmiaru i obfitości, przeładowania, przeciążenia, bogactwa informacji o nas i innych dochodzi do osłabienia oraz wyczerpania czujności emocjonalnej. Trudno się dziwić, że tak częstym powodem osobistych i rodzinnych tragedii: rozstań, rozwodów, krzywd i traumatycznych przeżyć są właśnie relacje wirtualne, wymagające coraz większej refleksji i profesjonalnego wsparcia społecznego. 
Badania Marty Majorek z 2015 roku, dokumentujące kody You Tube pod względem kultury partycypacji i kultury kreatywności, z wielkim niepokojem prezentują, że intymne i osobiste treści zaczynające się z reguły od niewinnej autoprezentacji siebie wśród nastolatek oraz młodzieży do trzydziestego roku życia, bardzo często szokują przekazem zawartych w nich treści erotycznych.

Wiele miejsca [w Internecie, a dokładnie na YouTube - M.Ś-M] poświęca się problemowi przedstawiania kobiet jako przedmiotów mających służyć zaspokajaniu męskich potrzeb seksualnych. Nie trzeba wykazywać się szczególnymi umiejętnościami, żeby odnaleźć tysiące filmów, które zdawać by się mogło, odzwierciedlają ten osąd. Wystarczy kilka kliknięć, by oglądać amatorskie nagrania prezentujące występy kobiet, zawierające zwykły taniec, a także przedstawiające obrazy od tego dalekie. Mowa tutaj o manifestowaniu przez wykonawczynie swej seksualności, co realizowane jest przez video ze striptizem (...) czy jednak tego typu video są przejawem wyłącznie uprzedmiotowienia kobiet, czy należy się kierować nasyconymi mizoginicznymi treściami komentarzami oglądających, czy też należałoby zmienić nieco punkt widzenia i zapatrywanie na tego typu występy $(\ldots)^{12}$.

Z powyższych ustaleń wynika, że seksualna bliskość, a raczej konwersja bliskości fizycznej na wirtualną, oddzielona od emocji jest jedynie ucieczką, prowadzi do dramatów osobowościowych, potęgując osamotnienie i depersonalizację relacji międzyludzkich. Podobnie jak mitologiczny Narcyz, ukarany, przyglądający się bez końca swojemu odbiciu, panicznie bał się odrzucenia, nie był szczęśliwy...

\section{Narcyzm jednostkowy a narcyzm społeczny}

Liberalne społeczeństwa zorganizowane wokół konsumpcji i przyjemności narzucają jednostkom wszelkie formy zachowania narcystycznego, jak na przykład zafascynowanie sławą, celebrowanie swoich osiągnięć, krótkoterminowość i brak stabilnego miejsca zamieszkania, pracy, rozbudzają oczekiwania społeczne, nie gwarantując ich spełnienia. Z jednej strony prowokują do poszukiwania szczęścia za wszelką cenę, z drugiej odrzucają poczucie słabości, bezradności, czy współczucia dla innych.

W psychologii osobowości ${ }^{13}$ diagnozując zespół osobowości narcystycznych, wyraźnie podkreśla się dezintegrację słabego "Ja" jednostki, która żyje w permanentnym lęku i zagrożeniu przed atakami na samego siebie, jest za-

${ }^{12}$ M. Majorek, Kod YouTube. Od kultury partycypacji do kultury kreatywności, Kraków 2015, s. 124-125.

${ }^{13}$ L. Cierpiałkowska (red.), Psychologia zachowań osobowości. Wybrane zagadnienia, Poznań 2004. 
wistna, gardzi zaletami i dobrami innych, panicznie boi się odrzucenia, ale często je prowokuje swoją agresją. Zupełnie inaczej prezentuje się na zewnątrz, jest fałszywa i nadyma się różnymi wspaniałymi zasługami, zdaje się być silna i niezwyciężona. Narcyzm kulturowy skutecznie wmawia jednostkom swoją wyjątkowość, oryginalność i bezinteresowność, pod pozorem wolnego wyboru funduje społeczeństwu wybór silnie zinstrumentalizowany rynkowo.

Cechy dystynktywne narcyzmu jednostkowego to przekonanie o swojej wyjątkowości i wielkości oraz nieustanne dążenie do admiracji i wzbudzania zazdrości ze strony otoczenia. Jednostki narcystyczne karmią się wizjami o swoim sukcesie, władzy, bogactwie. Kosztem emocjonalności oraz uczuciowości swojej i innych dążą do ideału w każdej dziedzinie. Jednostka taka nastawiona jest wyłącznie na realizację własnego "Ja" i tym samym nie może zrozumieć potrzeb drugiego człowieka. Jakikolwiek wymóg stawiany przez otoczenie zostaje przez jednostkę narcystyczną odczytany jako zniewolenie i ograniczenie jej wolności oraz przestrzeni. Skrajny typ narcyzmu można przyrównać do solipsyzmu (z łac. solus ipse - ja sam) - poglądu filozoficznego, w którym podmiot widzi jedynie siebie zasługującego na bezwzględny podziw, adorację, zachwyt i podmiotowe traktowanie, a wszystkich wokó siebie uprzedmiotawia.

Epoka " $\mathrm{Ja}^{\prime 14}$ obfituje w indywidualne pomysły, które zupełnie ignorują kontekst społeczno-kulturowy. Jednocześnie te same indywidualne projekty nie spajają tożsamości par, a jedynie wywyższają Ego jednostki. Widać to wyraźnie $\mathrm{w}$ terapeutycznych sposobach ratowania par, które paradoksalnie na rozbijający związki indywidualizm stosują praktyki mające wyłącznie podreperować i podbudować indywidualną wartość i Ego jednostki.

Z powyższego wynika, że narcyzm jako źródło zaburzeń jednostkowych człowieka koresponduje z narcyzmem kulturowym. Stało się tak między innymi na skutek atrofii socjalizacji bezpośredniej, pochodzącej od rodziny, szkoły, rówieśników. Współczesne społeczeństwo, w którym przychodzi młodym ludziom zdanym wyłącznie na siebie przygotowywać się do pełnienia ról społecznych, przyczynia się do narcystycznych postaw. Młodzież czerpie wiedzę z nigdy nie kończących się medialnych pomysłów na „najlepszy, najoryginalniejszy autowizerunek", które nakazują nieustannie podążać za tym co aktualne i zmieniać dotychczasowe wartości na rzecz innych, skupionych głównie wokół posiadania. Ponadto, rozprzestrzenianie narcystycznych postaw w kulturze uniemożliwia empatię na krzywdy społeczne, spowalnia reakcje na jakiekolwiek problemy innych, które nie są obejmowane refleksją; taka postawa skutecznie odbiera także autokrytycyzm. Na piedestale wyborów stoi

${ }^{14}$ Określenie użyte przez U. Beck i E. Beck-Gernheim w: Miłość na odległość. Modele życia w epoce globalnej, Warszawa 2013. 
jednostkowe zaspokajanie pragnień i „pozorna” wolność. Kultura narcyzmu przyczynia się zatem do dystansu społecznego, pod pozorem pracy nad sobą, autoanaliz i niezależności; „wolna” jednostka koncentruje się raczej na kolekcjonowaniu indywidualnych doznań, także w związku partnerskim.

Jak kwituje W.J. Burszta:

(...) współczesny narcyz tkwi po uszy w ideologii konsumpcyjnej, walczy nieustannie, aby on i jego rodzina miały więcej i lepiej, a konkurencja innych wymusza, aby nieustannie dbał o własny status, styl życia i tożsamość podmiotową, opartą na fetyszyzmie podmiotowym ${ }^{15}$.

Ponadto, jak słusznie zauważa W.J. Burszta, kultura narcyzmu powoduje zamęt tożsamościowy, myli pojęcie tożsamości i osobowości Ja z doświadczeniem Ego.

Ego jednostki jest zmienne, dopasowane do odbioru społecznego i panujących w danej kulturze wzorców tworzenia relacji. Ego doświadcza często relacji krótkotrwałej, opartej na romansie, czy tak zwanych przyjaźniach z plusem (czyli przyjaźni z jednorazową, niezobowiązującą przygodą seksualną). Prawdziwą tożsamość, osobowość i związek buduje się w realnym i stałym kontakcie z innymi bliskimi; nie można ich zatem traktować jak zbiór doświadczeń i projektów do zdobycia, a następnie porzucenia na rzecz „,atrakcyjniejszych" pomysłów.

Zogniskowanie na samym sobie jako dominującej cesze promowanej przez kulturę narcyzmu nakazuje spoglądać na budowanie związku właśnie w kategorii towaru, w który należy inwestować, a jeśli inwestycja się nie opłaca - nieustannie wymieniać, niczym w transakcji handlowej. Związki korzystają coraz częściej z porad internetowego love coacha, którego zadanie polega na wirtualnym nauczeniu umiejętności kochania i spełniania potrzeby bycia kochanym. Doradcy od miłości koncentrują się w pracy z klientem na zmianie podejścia do szukania partnera, na budowaniu wartości osoby. To love coach definiuje relacje "zdrowe”, czyli szczęśliwe i satysfakcjonujące dla indywidualnej jednostki. Problem polega na tym, że silna koncentracja na osobie, jej pragnieniach, przełamywaniu barier, lęków i ciągłe przyglądanie się jednostce, bardziej uczy narcystycznych, aniżeli partnerskich skryptów bycia razem. Współczesne pary są skutecznie przekonywane o słuszności i konieczności urozmaicania związku, który nie może tracić na atrakcyjności, rozumianej w kategorii posiadania (przystojnego i bogatego partnera, seksownej partnerki, stuprocentowej matki, żony, udanego życia seksualnego, bycia spełnionym) i wszystko to jest do osiągnięcia, pod warunkiem pracy z love

${ }^{15}$ W.J. Burszta, Narcyzm, kontrkultura i styl życia. W stronę kulturoznawstwa krytycznego w: cyfroteka.pl/katalog/ebooki? [data dostępu: 6.08.2015]. 
coachem. Jean Twenge ${ }^{16}$ amerykańska badaczka „Pokolenia My” z przerażeniem stwierdza, że na przestrzeni dwudziestu lat poziom narcyzmu wśród młodych ludzi, nie potrafiących realnie ocenić samych siebie i swoich potrzeb oraz nieumiejętnie selekcjonujących potrzeby, wzrósł aż o sześćdziesiąt pięć procent. Winą za ten fakt obarcza właśnie skuteczne mechanizmy kultury narcystycznego chwalenia i nagradzania jednostek, które na pochwały i nagrody nie zasłużyły. Jednocześnie wybujała pewność siebie i koncentracja na swoim wizerunku udoskonalanym poprzez markę, modę, posiadanie dotyczy częściej jednostek serwilistycznych, które bezkrytycznie chłoną trendy narzucane przez media, a ich liczba w społeczeństwie rośnie (narcyzm kulturowy odbiera autokrytycyzm).

Badacz życia społecznego A. Touraine słusznie zauważa, że

Wynoszenie prywatnego życia do rangi sprawy publicznej jest dziś jednym z najbardziej nośnych czynników stratyfikujących, a więc nie dziw, że jest też jednym z najbardziej upragnionych przywilejów ${ }^{17}$.

Wiele uwagi poświęca się współcześnie pytaniom o styl życia, niegdyś definiowany jako cechy charakteru, czy też umiejętność czerpania z życia wedle kompetencji społecznych. Na portalach społecznościowych w każdej minucie można poddać publicznej ocenie własny wizerunek, samopoczucie, własny, choć zmienny styl życia. Typowa jednostka o zaburzeniu narcystycznym, żyjąca w kulturze pełnej narcystycznych wizji, chce brylować w otoczeniu, odgrywając każdą rolę w sposób przedmiotowy, chce być widziana i podziwiana, bez względu na własne i innych odczucia. Jednocześnie, w swoich zachowaniach jest utwierdzana jako oryginalna, godna podziwu i naśladowania. Magdalena Szpunar ${ }^{18}$ oraz Beata Świątek ${ }^{19}$ pisząc o narcyzmie, jednogłośnie przyznają, że narcyzm jednostkowy może zaburzać całe życie społeczne i przenosić się do całych kultur uwikłanych w ekstazę wrażeń, szokowania i podziwiania jednocześnie.

\section{Zakończenie}

Pedagogika społeczna, której misja sprowadza się do pomagania, nie zawęża swojej działalności badawczej i naukowej tylko do osób z kręgu: biednych, bezdomnych, bezrobotnych i osamotnionych.

${ }^{16}$ J. Twenge, W. Keith, Epidemia narcyzmu, Warszawa 2009.

17 A. Touraine, Po kryzysie, Warszawa 2013, s. 319.

${ }_{18}$ M. Szpunar, Od narcyzmu jednostki do kultury narcyzmu, Kultura - Media - Teologia, 2014, 18, s. 106-116.

${ }^{19}$ B. Świątek, Narcyzm jako źródło zaburzeń orientacji życiowych człowieka, [w:] Narcyzm, red. J. Sieradzan, Białystok 2011, s. 187. 
Aktualne pytania pedagogiki społecznej daleko wykraczają poza pomoc społeczną oraz system świadczeń, ukazując nowy teren wsparcia dla relacji rodzinnych w warunkach zmian kulturowych.

Pedagodzy społeczni badający rodzinę coraz częściej akcentują zmiany jednostkowe i społeczno-kulturowe, związane z technicyzacją życia, które wpływają na jakość i kształt miłości oraz doświadczanych problemów w relacjach związkowych i rodzinnych.

Cała sieć problemów społecznych związanych z sekstingiem, sponsoringiem, prostytucją, cyberprzemocą i cyberpornografią, ale też homofobią nie stanowi wyłącznie zadania dla profesjonalnego wsparcia psychologicznego. Odpowiedzialność za treść i transfer sfery aksjonormatywnej ponoszą wszystkie struktury instytucjonalno-kulturowe, w tym przede wszystkim trójjednia przestrzeni edukacyjnych: jednostka - rodzina - szkoła, w tym szkoły wyższe - uniwersytety.

\section{BIBLIOGRAFIA}

Beck U., Beck-Gernsheim E., Całkiem zwyczajny chaos miłości, Wrocław 2013.

Beck U., Beck-Gernsheim E., Mitość na odległość. Modele życia w epoce globalnej, Warszawa 2013.

Burszta W.J., Narcyzm, kontrkultura i styl życia. W stronę kulturoznawstwa krytycznego w: cyfroteka.pl/katalog/ebooki? [data dostępu: 6.08.2015].

Burszta W., Majewski M., Sekuła E.A., Tożsamość i samotność: komentarze młodego pokolenia, Warszawa 2011.

Ben-Ze'ev A., Miłość w sieci. Internet i emocje, Poznań 2005.

Bieńko M., Intymne i prywatne praktyki codzienności. Studium socjologiczne, Warszawa 2013.

Castells M., Galaktyka Internetu, refleksje nad Internetem, biznesem i społeczeństwem, Poznań 2003.

Cierpiałkowska L., Psychologia zachowań osobowości. Wybrane zagadnienia, Poznań 2004.

Czerpaniak-Walczak M., Socjalizacja akademicka w czasach nadmiaru. O socjalizacji w (akademickim) krajobrazie medialnym, [w:] Pedagogika w społeczeństwie - społeczeństwo w pedagogice, red. A. Matysiak-Błaszczyk, E. Włodarczyk, Poznań 2016.

Giddens A., Nowoczesność $i$ tożsamość. Ja i spoteczeństwo w epoce późnej nowoczesności, Warszawa 2007.

Ilnicki R., Wirtualny habitus cyberkulturowy, Hybris, 2015, 31.

Ilouz E., Dlaczego miłość rani. Studium socjologiczne, Warszawa 2016.

Lasch C., The Culture of Narcissism: American Life in An age of Diminishing Expectations, New York 1991.

Luhman N., Semantyka mitości. O kodowaniu intymności, Warszawa 2003.

Majorek M., Kod YouTube. Od kultury partycypacji do kultury kreatywności, Kraków 2015.

Musiał M., Intymność i jej wspótczesne przemiany. Studium z filozofii kultury, Kraków 2015.

Portrety kobiet i mężczyzn w środkach masowego przekazu oraz podręcznikach szkolnych, red. R. Siemieńska, Warszawa 1997.

Stasińska A., Socjologia pary. Praktyki intymne w zwiazkach nieheteroseksualnych, Kraków 2018

Szlendak T., Socjologia rodziny. Ewolucja, historia, zróżnicowanie, Warszawa 2010. 
Szpunar M., Od narcyzmu jednostki do kultury narcyzmu, Kultura - Media - Teologia, 2014, 18.

Ściupider-Młodkowska M., Miłość w epoce Ja. Studium socjopedagogiczne, Poznań 2018.

Świątek B., Narcyzm jako źródło zaburzeń orientacji życiowych człowieka, [w:] Narcyzm, red. J. Sieradzan, Białystok 2011.

Touraine A., Po kryzysie, Warszawa 2013.

Twenge J., Keith W., Epidemia narcyzmu, Warszawa 2009.

Wanke M., E-mocje, przypadki rozszerzonej rzeczywistości afektywne, [w:] Studia z socjologii emocji. Podręcznik akademicki, red. A. Czerner, E. Nieroba, Opole 2011. 